\title{
LA ERECCIÓN DE NUEVAS SEDES EPISCOPALES EN EL REINADO DE FELIPE II: EL CASO DE LA CIUDAD DE XÀTIVA (REINO DE VALENCIA)
}

\author{
Germán RAMÍREZ ALEDÓN
}

\begin{abstract}
Resumen
En el Reino de Valencia la división episcopal viene determinada por la disputa de su territorio entre las Coronas de Castilla y de Aragón en el proceso de conquista cristiana. La reivindicación de la sede episcopal de la ciudad de Saetabis (Xàtiva), de origen visigodo, pronto fue anulada por la presión de Orihuela, desgajada de la diócesis de Cartagena en 1564. Xàtiva, por contra, fracasará en su intento. En estos conflictos el rey mantuvo una actitud que podemos calificar de «neutral», aunque influido por el problema morisco y la deficiente atención pastoral de sus súbditos.
\end{abstract}

\begin{abstract}
In the Kingdom of Valencia the episcopal division is determined by the dispute over the territory between the Castilian and Aragon Kingdoms during the process of the Christian Conquest. The restoration of the Episcopal See in the city of Saetabis (Xattiva), of Visigothic origen, was soon annulated due to pressure from Orihuela, separated from the diocese of Cartagena in 1564. Xàtiva, on the contrary, was unsuccessful. During these conflicts the King Philipp II maintained an attitude which we could describe as "neutral" although influenced by the moor problem and insufficient attention given to his subjects by the clergymen.
\end{abstract}

Entre las cuestiones que llamaron la atención del Rey Prudente durante su largo reinado destacan sobremanera aquellas relacionadas con la Iglesia como institución, las creencias religiosas y el ordenamiento de la vida monacal en los reinos de su vasto Imperio. Para Felipe II, la ortodoxia de la fe cristiana estaba por encima de cualquier otra consideración, como lo demuestran aquellas palabras que dirigiera a su hermana Margarita, después de haber aceptado el perdón a los confederados rebeldes de Flandes en 1566 y el cese de la actividad inquisitorial en aquellos territorios: "Antes que permitir ningún desvario en materia de religión, o tocante al servicio de 
Dios, prefiero perder todos mis dominios y cien vidas, si las tuviese, porque no quiero ser nunca rey de herejes»'. Lo religioso iba siempre unido, por otra parte, a lo político y la acción de gobernar; y esta actitud explica que se ocupara personalmente de dichos temas, incluso en los últimos años de su vida, cuando la salud le flaqueaba. Así lo quiso expresar Rafael Altamira en su estudio sobre el monarca cuando afirmaba: «Felipe practicó la doctrina de que la ejecución de su propósito religioso era cosa que le correspondía exclusivamente; y así, no permitió en ella ingerencias» ${ }^{2}$. Pero la visión excesivamente simple que se ha colegido de este planteamiento y de una abundante bibliografía situada más en la línea del combate ideológico que en el plano del análisis histórico, deja paso hoy a un juicio más ponderado sobre la actitud del monarca de la casa de Habsburgo en los asuntos religiosos, cruciales por otra parte para entender su reinado y la época que le tocó vivir: «La política religiosa de Felipe -ha señalado recientemente Henry Kamen-era progresista y en modo alguno se trataba de mera imposición del catolicismo tradicional. Dio un amplio y entusiasta apoyo a las novedades que introdujo Trento. Reformas de fondo y de forma en todas las órdenes religiosas, disciplina total del clero, educación de los curas párrocos, reforma de la práctica religiosa entre clero y feligreses, abolición de la misa y liturgia antiguas, adopción de una nueva misa, de un nuevo libro de oraciones, de nuevo calendario; adiestramiento de misioneros y establecimiento de escuelas; todo constituía un importante plan modernizador que el Rey trató de implantar» ${ }^{3}$.

Se esté o no de acuerdo con este planteamiento ${ }^{4}$, la actitud de Felipe II supuso un revulsivo en la religiosidad española de la segunda mitad del siglo, como convencido impulsor de las reformas emanadas del Concilio de Trento, que había concluido en 1563. De ese espíritu de renovación de la Iglesia española surge también la postura del monarca español en favor de la erección de nuevas sedes episcopales, que permitirían en muchos casos mejorar la atención pastoral y la cura de almas, tanto de los cristianos viejos como de los moriscos conversos, que en porcentajè respetable poblaban algunos de sus reinos, especialmente en la Corona de Aragón. Para llevar a buen puerto esos propósitos tuvo que mediar entre los intereses contrapuestos de la sede aspirante y la matriz de la cual se desgajaba el nuevo obispado: razones de toda índole, donde se entrecruzaban intereses económicos y de prestigio, envenenaron estos procesos, en los que tanto el Rey como la Santa Sede tuvieron que actuar con diplomacia y, en más de una ocasión, echar marcha atrás después de tomar la decisión de constitución del nuevo obispado.

I. Citado por Fidel PÉREZ MÍNGUEZ: Psicología de Felipe II. Madrid, 1925, pág. 143.

2. ALTAMIRA, Rafael: Felipe II, hombre de Estado. Su psicología general y su individualidad humana. Edición de José Martínez Millán, AEHM, Alicante 1997 (1ª ed.: 1950).

3. KAMEN, Henry: Felipe de España. Madrid, Siglo XXI, 1997, pág. 108.

4. De hecho ya han surgido voces que critican la visión «rosa» y dulcificada que da Kamen del reinado del monarca de la casa de Austria. Véase, en ese sentido, la breve recensión de Antoni SIMON I TARRÉS: «Felip II: una "imatge rosa"», L'Avenç, n 223 (marzo 1998), págs. 54-56. En el mismo sentido se ha expresado el profesor Manuel FERNÁNDEZ ÁLVAREZ en su monumental estudio Felipe II y su tiempo (Madrid, Espasa-Calpe, 1998), a quien Kamen ignora en buen medida, cuando el profesor Fernández Álvarez es uno de los más reconocidos especialistas en la época y el personaje. 


\section{LA ORDENACIÓN DE LAS SEDES EPISCOPALES HASTA EL SIGLO XVI. EL CASO VALENCIANO}

Como ya estudió hace años Demetrio Mansillas', desde el avance de las reinos cristianos sobre Al Andalus en el siglo XIII, que configuran los reinos medievales, se estableció la organización de la Iglesia española que con escasas variaciones permaneció inalterada hasta el reinado de Felipe II. Sólo habría que exceptuar de esa tendencia la formación de la provincia metropolitana de Zaragoza en 1318, la fundación del obispado de Canarias en 1404, la creación de la metropolitana de Valencia en 1492 y la restauración de las sedes episcopales de Granada, Málaga, Guadix y Almería, tras la conquista del reino de Granada en el reinado de los Reyes Católicos.

Pero esta organización que se configura en los siglos bajomedievales tiene sus antecedentes en la división eclesiástica de época visigótica y, en última instancia, en las divisiones político-administrativas de época romana. Las provincias de Hispania se corresponderán con las primeras sedes metropolitanas y las sedes episcopales emanan en muchos casos de los conventos jurídicos. Fue la división provincial de Diocleciano en el 297 la que servirá de referencia para la ordenación territorial de época visigótica, e incluso antes. Así, vemos cómo ya en el Concilio de Elvira (300-302) se muestra una palpable presencia de comunidades cristianas con la asistencia de 19 obispos y 24 presbíteros, con predominio del sur peninsular pero con la significativa asistencia de los obispos de Toledo, Zaragoza, León, Mérida, Loarre, Faro, Evora, Eliocroca (Lorca). Pero las informaciones más seguras proceden del siglo VI, especialmente de la Divisio Theodomiri, los Concilios de Braga (561 y 572) en época de dominio suevo, y los Concilios de Toledo ya en el marco del reino visigodo".

¿Cuál era la situación del territorio valenciano actual en esa etapa de conformación del cristianismo en la península ibérica? Del Concilio de Elvira no parece derivarse la existencia de una comunidad cristiana en tierras valencianas, ni en el de Sardes (342). La primera noticia documental que tenemos se sitúa a mediados del siglo VI: en el 546 tiene lugar en la ciudad de Valencia un Concilio provincial al que acuden seis obispos y un vicario, en representación del obispo Marcelo ${ }^{7}$. Se conocen sus nombres, pero no la sede de procedencia; tal vez, el único que podemos identificar es un tal Setabius, que posiblemente toma el nombre de la ciudad que representa, Saetabis, la actual ciudad de Xàtiva, cuya lucha por recuperar la sede episcopal desde el siglo XIII es un leit-motiv de su devenir histórico hasta el siglo XIX. Lucha que -digámoslo por adelantado- acabó en fracaso. En cualquier caso, aunque las fuentes escritas son de esa época, las excavaciones arqueológicas recientes demuestran una mayor antigüedad. El martirio o Passio del diácono Vicente (San Vicente Mártir, patrón de

5. MANSILLA REOYO, Demetrio: «La reorganización eclesiástica española del siglo XVI. I: AragónCataluña», Anthologica Annua (Roma), n 4 (1956), págs. 97-238, y n 5 (1957) para la Corona de Castilla. Estos estudios han sido incluidos en la obra de conjunto del mismo autor bajo el título Geografía. Eclesiástica de España. Estudio histórico-geográfico de las Diócesis. Roma, Iglesia Nacional Española, 1994, 2 tomos (los citados estudios en Tomo II).

6. Todas estas cuestiones son tratadas con amplitud en el libro de Demetrio MANSILLA: Geografía Eclesiástica..., l, págs. 92 y ss.

7. CÁRCEL ORTÍ, Vicente: Historia de la Iglesia en Valencia. Valencia, Arzobispado, 1986, 1 . págs. 35 y ss. 
Valencia) en el 304-305 y la existencia de su sepulcro en la ciudad del Turia animó la formación a principios del siglo IV de una comunidad cristiana ${ }^{8}$.

La división provincial de Hispania llevada a cabo en el 297 por el emperador Diocleciano tuvo una gran trascendencia, ya que sobre ella se van a articular no sólo las estructuras político-administrativas hasta la llegada de los musulmanes, sino la organización eclesiástica. Igual que sucederá en el reinado de Felipe II, quien se decide a apoyar algunas segregaciones y nuevas sedes sobre la base del criterio político (adecuación de fronteras entre reinos con límites de los obispados), también en época medieval -desde el siglo XI- la restauración de sedes episcopales trata de recuperar la memoria perdida de la organización eclesiástica visigoda. Hay aquí, por tanto, un goticismo evidente, que algunos autores rechazan hoy para interpretar el proceso de «reconquista y repoblación» (o conquista cristiana y colonización), pero que en el caso de las instituciones eclesiásticas parece bastante presente. Como decimos, esa división de Diocleciano estableció seis provincias en la diócesis hispana: Gallaecia, Lusitania, Baetica, Mauritania-Tingitania, Tarraconense y Cartaginense. Posteriormente, se añadió la Balearica, desgajada de la Cartaginense. Estas dos últimas surgían de segregar de la antigua Tarraconense (en un primer momento, la Citerior) la parte sur y buena parte de la meseta y valle del Duero. Tarraco era la capital de ésta, mientras Cartago Nova lo era de la Cartaginense. Pero el problema reside en establecer el límite entre ambas provincias en la zona costera levantina, es decir, en el ámbito territorial valenciano actual. Vicente Castell, que fue archivero diocesano de Valencia, defendió la pertenencia de la diócesis de Valencia a la provincia Tarraconense hasta los primeros años del siglo VI momento en que pasó a la Cartaginense, pero su punto de vista ha sido revisado por Cárcel Ortí y Mansilla Reoyo, quienes han demostrado de forma convincente cómo el territorio valenciano y, por tanto, la diócesis que en la ciudad se crea en el siglo IV, estuvo siempre en el ámbito de la Cartaginense y, por tanto, era sufragánea de ella ${ }^{9}$. Este hecho acarreará graves consecuencias, pues cuando en el 610 se traslade la sede metropolitana a Toledo, esta ciudad reclamará, tras la conquista del reino de Valencia por Jaime I, la primacía de la sede toledana frente a Tarragona, lo que producirá un extenso y complejo pleito que han estudiado Vicente Castell y Robert I. Burns ${ }^{10}$.

8. Ibidem, págs. 37-38. Vid. también LLOBREGAT, Enric: La primitiva cristiandat valenciana. Segles IV al VIII. Valencia, L'Estel, 1977, así como los estudios ya clásicos de Roque CHABÁS: Episcopologio valentino. Valencia, 1909, l , pp. 26 y ss. y el del canónigo José SANCHIS SIVERA: La diócesis valentina. Valencia, 1920, I.

9. CÁRCEL, V.: op. cit., I , págs. 41-43, aunque se muestra dudoso en sus conclusiones e, incluso, se inclina más por la tesis de Vicente Castell. Mansilla, sin embargo, afirma sin ambages que «el litoral mediterráneo no fue una excepción (a la política visigoda de respeto a la división de Diocleciano), y no podía serlo, porque Valencia no se independizó de Tarragona en tiempo de los visigodos, sino que su territorio perteneció a la Cartaginense desde la División hecha por Diocleciano el año 297» (Geografía Eclesiástica..., I, pág. 62).

10. CASTELL, Vicente: Un acontecimiento clave y decisivo en la historia de Valencia: el proceso sobre la ordenación de la diócesis valentina (1238-1246). Tres tomos (trabajo inédito que Cárcel Ort́ utilizó en su obra ya citada, pero que hasta hoy no ha visto la luz, después de haber fallecido su autor). BURNS, Robert I.: El Regne Croat de Valencia. Un país de frontera al segle XIII. Valencia, Tres i Quatre, 1993, págs. 545-594. 
En el actual territorio valenciano, dividido por la línea del Júcar en dos áreas culturales que ya Estrabón y Plinio definieron como Edetania (al norte del Júcar) y Contestania (al sur del citado río), se formaron otras dos sedes episcopales en los primeros siglos del cristianismo: la de Saetabis, capital de la Contestania ibérica, y la de Dianium (actual Dénia). Ambas están documentadas en los Concilios toledanos, junto a otras dos como son las de Illici (Elche) y Ello (posiblemente Elda), de las cuales tenemos escasas noticias ". Para el caso de Saetabis (Xàtiva), los cronistas de la época señalan el año 338, siendo pontífice San Silvestre y Constantino Magno emperador romano, como el de la creación de la sede setabitana, aunque no hay prueba documental ${ }^{12}$. Tenemos constancia de la presencia en diversos Concilios de seis obispos de la sede de Saetabis que están presentes desde el III Concilio de Toledo (589) hasta el XVI Concilio en el 693. A partir de aquí desaparece toda referencia a obispos de la sede setabitana. Con la invasión musulmana a principios del siglo VIII el territorio valenciano, y más en concreto la zona situada al sur de Júcar, quedó incluida primero en el reino de Tudmir, luego en la kora de Valencia y desde el siglo XI en un iqlìm, al parecer división de una kora ${ }^{13}$, cuya traducción podría ser la de «distrito» 0 «partido» y que se ha identificado con el interior del reino valenciano desde Castilla hasta el mar y de Xàtiva a tierras de Alicante, en lo que Escolano llamó a principios del siglo XVII el distrito «de las montañas» ${ }^{14}$.

La conquista cristiana supuso, en la mentalidad «colonizadora» y de recuperación de un territorio perdido hacía siglos, el inicio de reconstrucción de una realidad político-religiosa que ya no tenía sentido seis siglos después. Los intereses de castellanos y aragoneses-catalanes por ocupar las tierras valencianas acabó con la firma del tratado de Almizra en marzo de 1244, con el cual Jaime I se aseguraba el control de las tierras situadas al sur del Júcar hasta la línea fronteriza con Castilla en BiarBussot. De esos antecedentes eran buenos conocedores los miembros del cabildo de la Colegiata como se observa en los diversos Memoriales que envían a Felipe II durante su reinado. El monarca catalano-aragonés no permitió, sin embargo la restitución de las sedes de época visigótica situadas al sur del Júcar, pues este hecho hubiera supuesto la reclamación de Toledo como metropolitana de esas sedes ahora en tierras del Reino de Valencia, lo que el rey Jaime I -en un gesto que Burns califica de «protonacionalista»- no estaba dispuesto a consentir.

11. La cuestión de los orígenes de la sede episcopal de Xàtiva (Saetabis) ha sido tratada en diversas ocasiones por Agustí VENTURA. Véanse sus trabajos: «La frontera del Xúquer», Papers de la Costera, 1 (1981), pp. 31-48; L'església de Sant Feliu de Xàtiva. Xàtiva, 1979, pp. 17-20; «Xàtiva, una seu bisbal frustrada», Saó, núm. 131 (junio 1990), págs. 28-31 y «La catedralitat de Xátiva en l'època dels Borja», Xàtiva, Els Borja: una projecció europea. Xàtiva, Ajuntament, 1995, Vol. I , pp. 223-238. Son contribuciones interesantes las de Boix y Sarthou y, de forma especial, el Viage Literario a las Iglesias de España, de los hermanos Jaime y Joaquin Lorenzo Villanueva (vols. I y IV). los primeros autores en tratar el tema a principios del siglo XIX.

12. Así aparece en el Memorial de 1586 que la ciudad de Xàtiva dirigió al rey Felipe II (Archivo Municipal de Xàtiva: legajo 1.827, Sig. ant ${ }^{a}$ ).

13. ARIÉ, Rachel: España musulmana (siglos VII al XV). Vol. III de la Historia de España dirigida por Manuel Tuñón de Lara. Barcelona, Labor, 1984, págs. 84-88.

14. VENTURA, Agustí: «La catedralitat de Xàtiva...», pàg. 230; ESCOLANO, Gaspar: Décadas de la Historia de Valencia. Valencia, 1611. 
En cualquier caso, los monarcas aragoneses siempre estuvieron dispuestos a satisfacer las demandas de sus súbditos en lo concerniente a la reclamación de nuevas sedes episcopales. Buena muestra de ello es la promesa que Jaime II hizo el 22 de noviembre de 1317 al proponer al papa Juan XXII la creación del obispado de Xàtiva, que debía formarse sobre la base de los territorios del reino situados al sur de Júcar, los cuales formaban parte del obispado de Cartagena, sufragáneo de Toledo. Esa doble pertenencia de esta área -en lo político, al rey de Aragón; en lo religioso, al obispo de Cartagena y el metropolitano de Toledo- fue el motivo de la constante fricción entre las ciudades de Cartagena y Orihuela desde el siglo XIV hasta que Orihuela consiga la sede episcopal en 1564. La idea inicial de Jaime II, que hemos señalado, la cual asignaba la sede del sur del reino a Xàtiva, no prosperó ${ }^{15} \mathrm{y}$ fue la ciudad de Orihuela quien pronto va a sustituir en esa pretensión a la ciudad de los papas Borja.

A pesar de ello, las promesas reales no dejaron de ilusionar a los setabenses: el 5 de julio de 1347, Pedro IV de Aragón premiaba su fidelidad a su persona en la guerra de la Unión, concediendo a Xàtiva el título de Ciudad y la promesa de tratar con el Sumo Pontífice «que cree en esta ciudad una Sede y una Iglesia Catedral, proveyéndola de obispo, que tenga el obispado determinado bajo ciertos límites y dotado de ciertas rentas según dicho Señor Papa provea o bien ordene que se ha de hacer» ${ }^{16}$. El privilegio fue confirmado tres veces más entre 1348 y 1377 , pero de nada sirvió, pues la promesa quedó incumplida. También Teruel había conseguido el mismo año y por la misma causa el título de Ciudad y la promesa de ser erigida en sede episcopal, en una propuesta de contenido idéntico ${ }^{17}$. Teruel, sin embargo sí llegará a ver cumplidos sus anhelos en el reinado de Felipe II.

\section{LA REORDENACIÓN ECLESIÁSTICA EN EL REINADO DE FELIPE II}

Excepto los cambios antes señalados, la geografía eclesiástica de los reinos hispánicos apenas sufrió modificaciones hasta el reinado de Felipe II, quien siempre mostró interés en resolver los problemas derivados de la extensión y aumento de población de las diócesis, de la falta de atención pastoral de los fieles o de la situación de los moriscos. Ello indujo hace ya décadas a afirmar a Demetrio Mansilla que el problema de creación de nuevos obispados era de gran urgencia en la España del siglo XVI, por las razones apuntadas, por lo que «no fueron móviles políticos, sino de orden espiritual y religioso los que más movieron a Felipe II a pedir y llevar a cabo la

15. MANSILLA, Demetrio: «La reorganización eclesiástica...», págs. 102-103, quien sigue el trabajo fundamental de J. VINCKE: Documenta selecta mutuas civitatis Arago-Cathalaunicae ef ecclesiae relationes illustrantica. Barcelona, 1936, págs. 216-217.

16. Una versión incompleta traducida del latín al valenciano la publicó Pere $\mathrm{M}^{\mathrm{a}}$ ORTS en su libro Història de la Senyera al País Valencià. Valencia, Tres i Quatre, 1979, págs. 52-55. La versión completa del texto latino la ha publicado recientemente Agustí VENTURA en «650 aniversari del títol de Ciutat de Xàtiva», Noticias 7 Días, n² 28 (12-7-97), pág. 12.

17. El texto de la promesa a Teruel fue publicada por Blasco Lanuza en 1622 y lo reproduce Demetrio Mansilla en «La reorganización eclesiástica...», pág. 182. Mansilla llega a dudar que el rey Pedro IV se tomara muy en serio estos proyectos, aunque sí reconoce que en 1423, Teruel había obtenido el título de Colegiata. Xàtiva lo había conseguido diez años antes, siendo Papa Benedicto XIII (el Papa o antipapa Luna), por lo que fue necesaria una confirmación posterior. 
erección de nuevas sedes» ${ }^{18}$. Sea como fuere, es difícil separar la acción política de las razones «de orden espiritual» en un momento en que ambos planos de la acción de gobierno estaban estrechamente imbricados. La política asimilacionista del monarca respecto de la minoría morisca no parece residir sólo en razones pastorales, sino plenamente políticas, como se verá más tarde en el reinado de su sucesor Felipe III.

La reordenación de sedes episcopales en el reinado del Rey Prudente tiene dos ámbitos territoriales bien diferenciados por razones políticas e históricas: la Corona de Aragón y la Corona de Castilla. En el primer caso, los procesos de formación de nuevas sedes fue más amplio y de mayores consecuencias. Solo de forma muy breve debemos referirnos a ellas ${ }^{19}$. Orihuela, que ya en el siglo XIV (aunque no hemos podido precisar en qué momento) sustituye a Xàtiva como cabeza de una futura sede episcopal, se erige por vez primera en obispado a raíz del Concilio de Basilea, después que Alfonso V el Magnánimo apoyara la idea y concediese el título de Ciudad en 1437, conditio sine qua non para alcanzar la catedralidad. Recordemos que un siglo antes Xàtiva y Teruel ya habían alcanzado este premio y la promesa de ser erigidas en sedes episcopales. Pero las razones para apoyar a Orihuela residían en el enfrentamiento que mantenía con la diócesis de Cartagena, y, por extensión, con Castilla, al considerar el monarca aragonés que el metropolitano de Toledo ejercía una jurisdicción -la eclesiástica- en un territorio que no era del reino de Castilla. Aunque el Concilio accedió a la petición de Alfonso V en 1442, pronto fue anulada la decisión por el papa Eugenio IV, quien se enfrentaba a un cisma en la persona del antipapa Félix, apoyado por el monarca aragonés. A ello debe sumarse la oposición de Castilla que apoyaba plenamente las pretensiones del obispo de Cartagena. Un segundo intento durante el pontificado de Julio II, quien en 1510 concedía a Orihuela el obispado, también acabó fracasando por la cambiante actitud de Fernando el Católico, la persistente oposición de Cartagena y la clara postura de Carlos V opuesto a la separación. Con el inicio del reinado de Felipe II se abren nuevas expectativas para las demandas de Orihuela: el problema morisco, el crecimiento demográfico o la deficiente atención pastoral acabaron decidiendo al monarca a tomar partido en el asunto y lograr en el consistorio de 14 de julio de 1564 la diócesis oriolana, dependiente del metropolitano de Valencia. Las razones eran obvias para el propio Felipe II, quien entendía que la aspiración de la Corona de Aragón y más en concreto del reino de Valencia era que sus habitantes no dependieran eclesiásticamente del reino de Castilla así como «la diversidad de lengua y legislación», en clara referencia a los fueros y la lengua de los valencianos ${ }^{20}$. Se aprovechaban, además, dos circunstancias: la celebración de Cortes en Monzón y la muerte del obispo de Cartagena don Esteban de Almeida, en marzo de 1563.

La erección de nueva sede episcopal en Orihuela no pacificó los ánimos de Cartagena que siguió durante muchos años reclamando rentas de la división territorial.

18. MANSILLA, Demetrio:«La reorganización...», pág. 99.

19. Un detallado estudio to hace Demetrio Mansilla en sus artículos y en el tomo II de su Geografía Eclesiástica de España, ya mencionada, y que recoge una abundante bibliografía.

20. El proceso de obtención de la sede para Orihuela en MANSILLA, D.: «La reorganización...», págs. 100-132; VILAR, Juan Bautista: Orihuela, una ciudad valenciana en la España Moderna. Murcia, Caja de Ahorros Provincial de Alicante y Murcia, 1981, Tomo 4, vol. III, pp. 767 y ss.; NAVARRO BOTELLA, J.M.: El primer Sínodo de Orihuela (1569). Alicante, Caja de Ahorros Provincial, 1979. 
Semejantes y, en algunos casos más duras, fueron las respuestas de las sedes matrices en otros casos de separación y nueva erección: así, Barbastro y Jaca al separarse de Huesca en 1571, después de una pugna de siglos. O la desmembración del obispado de Segorbe-Albarracín, formado así en 1247 y mantenido hasta su separación en 1577. En este caso, las razones de distancia física eran evidentes (pues la diócesis no formaba un territorio continuo, en donde se interponía la cesaraugustana), pero aún pesó más en el ánimo del monarca la predominancia en el territorio de Segorbe de una abundante población de cristianos nuevos que había que atender y cristianizar de forma efectiva. Las pugnas entre ambas diócesis separadas se mantuvieron durante casi dos décadas después de la bula de erección de la sede de Albarracín y por razones puramente económicas o de rentas. En el caso de Teruel, cuya promesa como hemos visto ya la había formulado Pedro IV de Aragón en 1347, fue planteado a Roma al mismo tiempo que la separación de Segorbe-Albarracín, en lo que parece ser un intento de reordenación de las sedes de los reinos de la Corona de Aragón. En el caso de Teruel, el proceso fue más breve ${ }^{21}$. La muerte del arzobispo de Zaragoza en enero de 1577, acejeró el proceso en Roma, basándose en la gran distancia respecto de la capital aragonesa y el gran peso de la población morisca. En este caso apenas hubo oposición por parte de Zaragoza, aunque la bula despachada el 15 de julio de 1577 no fue expedida hasta el mes de junio del año siguiente, por razones de prudencia política. El arreglo episcopal se completó -por lo que hace a la Corona de Aragón- con la creación de la diócesis de Solsona, segregada de Urgell en 1593.

En el ámbito de la Corona de Castilla destaca de forma especial la creación de la sede de Valladolid, segregada de Palencia, después de dura pugna, en las postrimerías del año 1595, después de que el Papa Clemente VIII accediera a la petición de la que otrora fuera capital del reino castellano y otorgara en el mismo acto el título de ciudad, lo cual tuvo que confirmar Felipe II en los primeros días de 1596. En este asunto tuvo el rey interés especial y personal ${ }^{22}$; por algo había nacido en dicha ciudad, que había sido corte de la monarquía española hasta 1561.

\section{LA PETICIÓN DE XÀTIVA: FUNDAMENTOS Y RAZONES DE UNA PRETENSIÓN FRUSTRADA}

Orihuela y Xàtiva, dos ciudades valencianas situadas al sur del río Júcar habían conseguido de Benedicto XIII la bula de erección en Colegiata en el mismo año de $1413^{23}$. Pero si en el caso de Orihuela - como hemos visto- la batalla fue ganada a la

21. MANSILLA, D.: «La reorganización...», págs. 180-190; ALDEA, Q; MARÍN, T, y VIVES, J.: Diccionario de Historia Eclesiástica de España. Madrid, Instituto Enrique Flórez, 1975, Tomo IV, págs. $2.558-2.562$.

22. Un detallado análisis del proceso y de las diferencias con el cabildo de Palencia en CABEZA RODRÍGUEZ, Antonio: «Lá difícil creación del obispado», en EGIDO, T. (Dir.): Historia de la Diócesis de Valladolid. Valladolid, Arzobispado-Diputación Provincial, 1996, pp. 61-96. También MANSILLA, D.: Geografía Eclesiástica..., II, pp. 518 y ss.

23. Esta bula fue concedida por Pedro de Luna (el papa Luna), en Peñíscola, el 13 de abril de 1413 y el 13 de diciembre para Xátiva. Al término del Cisma de Occidente, cuando la Corona de Aragón vuelve a la obediencia de Roma, la bula fue revalidada por el Papa Martin V en Florencia el 19 de abril de 1419. Para el conocimiento de la Colegiata de Xàtiva y de su proceso de constitución es fundamental el estudio de ALONSO, J.; BOLUDA, A. y PONS, V.: «L'arxiu de la Col.legiata de Santa Maria de Xàtiva. Inventari i aproximació històrica», Papers de la Costera (Xàtiva, 1992), págs. 219-238. 
postre y la reivindicación se fundamentaba en argumentos políticos por el enfrentamiento Castilla-Corona de Aragón, en el caso de la ciudad de Xàtiva la petición de la catedralidad suponía recortar las rentas y preeminencia en el reino valenciano de su capital, la ciudad de Valencia. Es por ello, que desde el siglo XIV el Consell municipal de ésta y el cabildo catedralicio manifestaron una oposición frontal a esta pretensión de los de Xàtiva, oposición mantenida siglo tras siglo hasta su fracaso definitivo después de la segunda restauración absolutista de Fernando VII en 1823.

Sin lugar a dudas, la promesa de Jaime II en 1317 de crear un nuevo obispado de las tierras del sur valenciano, integradas durante su reinado por las Sentencias arbitrales de Torrellas (1304) y Elche (1305), cuya sede estuviera en Xativa, fue pronto abandonada por la propia dinámica histórica, ya que Orihuela era cabeza de Gobernación de las nuevas tierras incorporadas situadas al sur de la línea Biar-Bussot, establecida como frontera sur del reino de Valencia en los años de la conquista cristiana a manos de Jaime I. Por tanto, ya desde fecha muy temprana el proyecto de nuevo obispado se centraba en Orihuela con la finalidad de desligar su territorio de la influencia del obispado de Cartagena y, en consecuencia, de la de Castilla. Después de 1564, cuando Orihuela consiga su propósito tras denodada lucha e interdictos de los de Cartagena (incluso con la notable indiferencia de algún miembro de la familia Borja ${ }^{24}$, natural de Xàtiva), las posibilidades de que la antigua Saetabis fuera erigida en sede episcopal eran prácticamente nulas, por dos razones fundamentales: la primera, porque la segregación no se justificaba como una adecuación de los límites eclesiásticos a los políticos, ya que el territorio que se pretendía desgajar era parte del obispado de Valencia y todo él estaba dentro del reino de Valencia; la segunda, porque la poderosa oligarquía del cap i casal, de la capital del reino, y de su Cabildo metropolitano no estaba dispuesta a ceder su poder, privilegios, rentas e influencia en el conjunto del reino valenciano.

Aunque la petición de los de Xàtiva se venía produciendo desde el siglo XIII, es a partir del reinado de Felipe II cuando se incrementa el interés y la «presión» ${ }^{25}$, espoleada la ciudad por el éxito de Orihuela, la convocatoria de Cortes en Monzón (1563-64) y la visita de Felipe II a la ciudad de Valencia en abril de 1564. Con dicho motivo presentaron al rey un Memorial que no tuvo respuesta, pues en una carta remitida por los jurados y justicia de la Ciudad de marzo de 1568 vuelven a insistir en la petición. Cuando casi dos décadas después, en enero de 1586, el monarca vuelva a visitar el reino de Valencia, la ciudad de Xàtiva lo recibe con gran agasajo y le presenta dos extensos memoriales de petición de la catedralidad, suscritos por ambos ca-

24. Rodrigo de Borja, sobrino de Calixto III (Alfons de Borja), fue obispo de Cartagena (desde 1490) y de Porto, cardenal, y residió en Roma como protegido de su tío. Como ha señalado Juan Bautista Vilar, «Borja, prelado absentista, ante todo estaba interesado en mantener buenas relaciones con el clero de Murcia...El paso de este valenciano por la sede murciana, lejos de propiciar un acercamiento entre sus diocesanos enfrentados, supuso un recrudecimiento de la crisis latente» (Orihuela, tha citudad valenciana.., pág. 772).

25. Hemos estudiado con detalle el clima y las motivos de la petición de Xàtiva al monarca en «La qüestió de la catedralitat a les acaballes del segle XVl», Papers de la Costera (Xàtiva, 1998), núm. 11, págs. 38-61, donde se incluyen en apéndice los principales memoriales que el Cabildo y el Consell municipal enviaron a Felipe II y Felipe III entre 1568 y 1617. 
bildos, el eclesiástico y el municipal ${ }^{26}$. Las expectativas que abren estas visitas explican el acuerdo del Cabildo de la Colegiata de 19 de septiembre de aquel año, por el que se acuerda que el canónigo Gaspar Joan de Gallach vaya, en nombre del Cabildo, «a la Cort de Sa Majestat en la Vila de Madrit, Regne de Castella, a tractar los negocis que per part de aquest Il.lustre i Molt Reverent Capitol li seran comesos y acomanats y donats en memorial... ${ }^{27}$.

Seis años después, en 1594, el Cabildo de la colegiata setabense presentaba un nuevo y extenso Memorial al rey, que comprendía la propuesta de arreglo parroquial, límites territoriales y división de rentas entre el obispado de Valencia y el que se había de erigir en Xàtiva. Los de esta ciudad se armaban de argumentos, después de los éxitos de Teruel, Albarracín y Solsona, en el ámbito de la Corona de Aragón, y del muy cercano de Valladolid en la de Castilla. Pero tampoco en esta ocasión la pretensión alcanzó sus objetivos, por la pertinaz y acusada oposición del Cabildo y Consell municipal de Valencia. Esta oposición, recelo y desconfianza mutua tenía profundas raíces que se remontan a los siglos bajomedievales, como ha demostrado Agustín Rubio ${ }^{28}$, especialmente por el tema del aprovisionamiento de trigo y otros productos básicos para la capital del reino. En este clima de entusiasmo por la aspiración a convertirse en sede episcopal se ha de situar el acuerdo del Consell municipal del 16 de octubre de 1596 para iniciar la construcción de un nuevo templo sobre la degradada y antigua mezquita consagrada como templo cristiano en 1248 , obras que se iniciaron en el mes de enero del año siguiente ${ }^{29}$.

Los argumentos de la demanda, al igual que sucede en los otros casos señalados, se basaban en cinco puntos que hemos extraído de la lectura del Memorial de 1594, aunque no se exponen allí de forma sistematizada:

A) En primer lugar, el prestigio de la Ciudad de Xàtiva dentro del Reino de Valencia, ya que disfrutaba del título de Ciudad desde 1347, por las razones apuntadas y con oposición de Valencia que apoyó en la guerra de la Unión el bando antirrealista; era la segunda ciudad con voto en el brazo real de las Cortes valencianas, gozaba de una numerosa e influyente nobleza, era la patria de los dos papas Borja, la segunda ciudad del reino también en población, cabeza de una subgobernación y de una Bailía, y disfrutaba de la categoría de Colegiata desde 1413 y, de forma especial, poseer unos antecedentes históricos (la sede de época visigótica) que constituían, sin duda, un buen curriculum para optar a ser de nuevo sede episcopal. Pero el Capítulo de Valencia en Memorial del mismo año remitido al rey, desmontaba todos estos argumentos, especialmente los históricos, con un razonamiento que podemos denominar «antigoticista», cuando afirma «que en las cosas de govierno de lo espiritual y temporal solo se observa lo que se ha instituido despues que Hespaña se libró del poder de los moros, particularmente en el Reyno de Valencia, y assi jamás se ha attendido

26. De ambos Memoriales se conserva copia en los Archivos locales: Archivo Municipal de Xàtiva (AMX): leg. 1.827 y Archivo Histórico de la Colegiata de Xàtiva (AHCX): caja 29.

27. A.M.X.: Libro n 1326. Cabildos generales de la Seo de 1570 a 1628 , fols. 232r-233r.

28. RUBIO VELA, Agustín: Epistolari de la València medieval. Valencia, Universidad, 1985, pág. 82 y «Xàtiva i València en els segles XIV i XV: el rerefons econòmic d'unes relacions conflictives», Xàtiva, Els Borja. Una projecció europea. Xàtiva, 1995, Vol. I , pp. 211-222.

29. SARTHOU, Carlos: Datos para la Historia de Játiva. Xàtiva, 1933, I, págs. 254 y ss. 
las obserbancias del tiempo de los Godos ni otros anteriores, porque el estado de la Christiandad en la primitiva Iglesia era muy diferente, y en Hespaña avía pocos christianos y la jurisdiccion de los Obispos no tenia forma ni fuerzas y asi se han extinguido y perdido todos los drechos y privilegios que antiguamente solian tener todas las Iglesias y Comunidades ${ }^{30}$. Afirmaciones, que -como hemos dicho en otro lugarrozan el cinismo, cuando sabemos que la conquista del reino de Valencia fue una Cruzada contra tierra de «infieles» y sarracenos. Frente a esa ruptura, los de Xàtiva defendían la continuidad de la época visigótica con la que se restablece tras la conquista cristiana.

B) El segundo argumento era la importancia económica y demográfica de Xàti$v a$, en un momento (segunda mitad del XVI) de clara expansión poblacional, que a principios del XVII tenía unos 10.000 habitantes, de los cuales un $20 \%$ eran moriscos que vivían en la morería. Además, en su término particular había una notable presencia de población morisca. En conjunto, la población había crecido un $25 \%$ en la segunda mitad del XVI, por ello era lógico demandar una mayor atención pastoral tanto para los cristianos viejos como para los nuevos, «pues se augmenta el rebaño es menester se ponga más guarda y señalen pastores y atalayas, y pues la mies es mucha y los obreros son pocos es menester rogar al Señor de la mies que imbie obreros a ella» (Memorial de 1594).

C) El tercer argumento era la situación geográfica de la ciudad, como encrucijada entre Castilla y el sur del reino valenciano. En este caso la lejanía de Valencia, el tener que cruzar el Júcar -que carecía de puente-para ir a la capital, eran impedimentos que hacían necesario desligar a los habitantes de las montañas alicantinas y del interior valenciano de su dependencia de Valencia para tener más cerca el «pastor» que los cuidara espiritualmente. No hay que olvidar, además, como hace el Memorial, las dificultades de comunicación que se producían en la época (otoño) en que se inundaba el río y hacía impracticable el camino, «y es cosa más que contingente venir estas avenidas de ríos en la Semana Santa, al tiempo quando se va a Valencia por la chrisma yóleos Santos...».

D) El cuarto argumento estaba relacionado con las rentas de la Colegiata, su escasez, la extracción que hacía el Cabildo de Valencia de las rentas de la comarca setabitana y las que se llevaba el arcediano de Xàtiva que residía en Valencia. Los orígenes de esta situación gravosa para el cabildo setabense se remontaban a los tiempos de la conquista cristiana, cuando «el obispo de Valencia y sus canónigos y dignidades se tomaron los frutos de Xativa y la dejaron sin dignidad, hecha vicaría perpétua y sin frutos [...]; de aquí pues ha nacido la pobreza y miseria que se padece y de ella nacen las indecencias sobredichas...». La solidez económica de los obispados era defendida por Valencia como una barrera frente al enemigo exterior e interior: en efecto, la proximidad de la costa africana (o Berbería, como era llamada entonces) era una obsesión para las autoridades políticas y religiosas de las últimas décadas del XVI y para el propio monarca y está en la base de los argumentos de la expulsión decretada en 1609, ya que los moriscos eran considerados «quintacolumnistas» al servi-

30. A.H.C.X.: caja 29. Manuscrito incompleto, sin datación (pero de 1594). En el Archivo de la Catedral de Valencia se conserva abundante documentación sobre el tema, pero su consulta nos ha sido impedida por las obras que se llevan a cabo desde 1993. 
cio del turco y de la piratería del norte de África. Como dice el mencionado memorial del Cabildo de Valencia, «el Arzobispado y Reyno de Valencia está en partes marítimas y rodeado y poblado de christianos nuevos».

E) Por último, las razones espirituales que se mostraban como esenciales, encubrían muchas veces intereses más mundanos relacionados con las rentas episcopales, la administración de la mensa canonical, los frutos primiciales o la percepción de diezmos. Ambas cosas iban estrechamente unidas como muestra el razonamiento que da el Cabildo de la Seo setabense en su Memorial dirigido al rey en 1586: la escasez de rentas actúa en perjuicio del prestigio sacerdotal «y lo que peor es, enflaquece la buena administracion de los sacramentos, la celebracion de las horas canonicas, of $i$ cios y culto divino en la dicha Iglesia, de que V. Magestad es tan zeloso... ${ }^{31}$.

La propuesta de arreglo que propone el Cabildo de Xàtiva en 1594 tiene bastantes semejanzas con el de Teruel y el de Albarracín en lo que se refiere a la organización del personal y lo podemos resumir de la siguiente forma:

\begin{tabular}{|c|c|}
\hline $\begin{array}{c}\text { Situación en } 1594 \text { del personal de la } \\
\text { Colegiata de Santa María }\end{array}$ & $\begin{array}{c}\text { Propuesta de personal del Cabildo de la } \\
\text { sede episcopal de Xàtiva }\end{array}$ \\
\hline $\begin{array}{l}\text { CANÓNIGOS: } 15 \text {, de los cuales tres son } \\
\text { cargos de gobierno (dignidades): } \\
\text { - Deán } \\
\text { - Sacristán } \\
\text { - Capiscol (maestro de Coro) }\end{array}$ & $\begin{array}{l}\text { CANÓNIGOS: } 19 \text {, de los cuales además } \\
\text { de las tres dignidades (Deán, Sacristán, } \\
\text { Capiscol), se añaden tres dignidades más: } \\
\text { - Canónigo del Santo Oficio de la } \\
\text { Inquisición } \\
\text { - Arcediano de Xàtiva (suprimiendo el de } \\
\text { Valencia) } \\
\text { - Arcediano de Montesa }\end{array}$ \\
\hline $\begin{array}{l}\text { OFICIOS: } 7 \text {, de los cuales, } \\
\text { - dos hebdomadarios } \\
\text { - Dos sub-capiscoles } \\
\text { - Dos diáconos } \\
\text { - Un sub-sacristán }\end{array}$ & $\begin{array}{l}\text { OFICIOS: Eliminarlos y sustituirlos por } \\
12 \text { «raciones» (o «racioneros») } \\
\text { OTROS OFICIOS: un Maestro de } \\
\text { ceremonias, un maestro de capilla, } \\
\text { cantores, un organista, un sub-sacristán, } \\
\text { cuatro capellanes, un pertiguero, un } \\
\text { campanero, infantes de coro, dos } \\
\text { escolanes i «otros ministros». }\end{array}$ \\
\hline BENEFICIOS: 62 & BENEFICIOS: no consta \\
\hline
\end{tabular}

Por lo que hace a las rentas, cuestión clave, la propuesta suponía desgajar entre un 20 y un $25 \%$ de las de Valencia, asignando también parte de las del convento de la Valldigna, que también manifestó su oposición a la propuesta de Xàtiva, pues más de la mitad de sus rentas deberían pasar a la nueva sede. La propuesta de arreglo ${ }^{32}$ sería la siguiente:

32. Un análisis detallado de esta propuesta la hemos realizado en «La qüestió de la catedralitat...», pp. 46-50. 
- Renta que produce Valencia (por arrendamiento): 70.000 ducados (en 1556 eran tan solo 15.000 ducados). Según el Cabildo de Valencia esta cantidad era muy inferior.

- Renta que se detrae de Valencia para darla a Xàtiva: 15.000 a 16.000 ducados.

\section{Reparto de las rentas:}

1. Supresión del arcedianato de Xàtiva, cuya renta (6.000 ducados) pasaría al nuevo obispado.

2. Convento de la Valldigna: de su renta (15.000 ducados) pasarían 8.000 a 9.000 ducados al nuevo obispado. El obispo sería al mismo tiempo abad del monasterio con una renta de 7.000 a 8.000 ducados.

3. Frutos de la zona del obispado que corresponderían al arzobispo, canónigos y pabordías de Valencia (unos 20.000 ducados).

Todas estas propuestas quedaron paralizadas ya en el mismo año 1594 , cuando Felipe II por presiones del Cabildo de la sede valenciana, comunicaba a los de Xàtiva su decisión de suspender «la plática de erección de su Iglesia en Catedral», en carta de 29 de noviembre de $1594^{33}$. Esta suspensión temporal no desanimó a los de la ciudad de los papas Borja; el silencio impuesto por Felipe II, se rompió días después de la muerte del arzobispo de Valencia Juan de Ribera, en enero de 1611. En esta ocasión, el Cabildo setabense echó mano del prestigio del dominico Fray Tomás de Maluenda, natural de Xàtiva, quien el 16 de enero de quel año escribía al confesor y compañero de religión, Fray Luis de Aliaga, para que mediara en la cuestión de la catedralidad. Tampoco sus gestiones tuvieron éxito. El tema vuelve a ser planteado en varias ocasiones a lo largo del XVII, pero es a partir de 1760 , en el reinado de Carlos III, cuando recibe un decidido impulso que se corona en la época de las Cortes de Cádiz, con la obtención -bien que de forma efímera- de aquel sueño quimérico que se remontaba a los años de la conquista del rey Jaime el Conquistador. 